Eurasscience Journals

Eurasian Journal of Forest Science (2015) 3(2): 12-18

\title{
THE EFFECT OF DIFFERENT DOSES OF NITROGEN (N) APPLICATION ON THE ANTIOXIDANT ACTIVITY AND PHENOLIC MATERIAL INGREDIENT OF SORREL (RUMEX ACETOSA L.)
}

\author{
Sevinc Adiloglu1*, Funda Eryilmaz Acikgoz ${ }^{2}$, Figen Daglioglu ${ }^{3}$, Sila Barut Gok ${ }^{3}$, Deniz Damla Altan ${ }^{3}$ \\ ${ }^{1}$ Namik Kemal University, Faculty of Agriculture, Department of Soil Science and Plant Nutrition, Tekirdag. \\ Corresponding Author: sadiloglu@hotmail.com \\ ${ }^{2}$ Namik Kemal University, Vocational College of Technical Sciences, Department of Plant and Animal Production, \\ Tekirdag \\ ${ }^{3}$ Namik Kemal University, Faculty of Agriculture, Food Engineering Department, Tekirdag
}

\begin{abstract}
In this study, the effect of different doses of nitrogen $(\mathrm{N})$ application on the antioxidant activity and phenolic material ingredient of sorrel (Rumex acetosa L.) are investigated. In the test, four various doses of nitrogen $\mathrm{NH}_{4} \mathrm{NO}_{3}$ fertilizer $\left(\mathrm{N}_{0}: 0 \mathrm{~kg} / \mathrm{da}, \mathrm{N}_{1}: 4 \mathrm{~kg} / \mathrm{da}-16 \mathrm{ppm}, \mathrm{N}_{2}: 6 \mathrm{~kg} / \mathrm{da}-24 \mathrm{ppm}, \mathrm{N}_{3}: 8 \mathrm{~kg} / \mathrm{da}-32 \mathrm{ppm}\right)$ have been applied to the plants. As a result, it has been determined that the antioxidant activity and phenolic compounds of Sorrel (Rumex acetosa L.) have parallels with the increase in the application of nitrogen. Increasing the amount of phenolic compounds and antioxidant group compounds, in which they are included, leads to positive impact on above-mentioned effects of Rumex. In this context, it can be said that increasing phenolic compounds and antioxidant activity, which are obtained as a result of this study, with different dose $\mathrm{N}$ applications can increase the positive effects of this plant to human health.
\end{abstract}

Keywords: Nitrogen $\left(\mathrm{NH}_{4} \mathrm{NO}_{3}\right.$ ), Sorrel (Rumex acetosa L.), antioxidant activity, phenolic material ingredient, functional food

Özet

Bu çalışmada kuzukulağına (Rumex acetosa L.) uygulanan farklı dozlardaki azot gübresinin antioksidan aktivitesine ve kuzukulağında muhtevi uçucu madde içeriğine etkisi araştırılmıştır. Araştırmada bitkilere $\left(\mathrm{N}_{0}: 0 \mathrm{~kg} / \mathrm{da}, \mathrm{N}_{1}: 4 \mathrm{~kg} / \mathrm{da}-\right.$ $16 \mathrm{ppm}, \mathrm{N}_{2}: 6 \mathrm{~kg} / \mathrm{da}-24 \mathrm{ppm}, \mathrm{N}_{3}: 8 \mathrm{~kg} / \mathrm{da}-32 \mathrm{ppm}$ ) dört farklı dozda gübreleme uygulanmıştır. Sonuç olarak, azot gübresi miktarındaki artışa paralel olarak antioksidan aktivitesinde ve kuzukulağında muhtevi uçucu madde içeriği miktarında artış gözlemlenmiştir. Yukarıda da bahsedildiği gibi, uçucu bileşiklerin ve antioksidan grubundaki bileşiklerin artması, Rumex'in yukarıda bahsedilen etkilerini arttırmaktadır. Bu bağlamda; uçucu bileşiklerin ve antioksidan seviyelerinin farklı azot gübrelemesi uygulamalarına bağlı olarak artması, bu bitkinin insan sağlığı için elverişliliğini de arttırmaktadır.

Anahtar kelimeler: Azot $\left(\mathrm{NH}_{4} \mathrm{NO}_{3}\right.$ ), Kuzukulağ1 (Rumex acetosa L.), antioksidan aktivitesi, uçucu madde içeriği, işlevsel besin.

\section{INTRODUCTION}

Sorrel (Rumex acetosa L.) belongs to Polygonaceae family and is known as Rumex acetosa L. Although it is not cultivated, it is commonly and spontaneously produced in most places of our country. It has an importance among the herbs that are sold in spring, summer, and fall seasons (Baytop 1984, Tabata et al. 
1994, Vural et al. 2000, Karataş 2013). It has been known that when consumed as raw, sorrel leaf decreases blood sugar, and its extract shows anti-tumor, anti-microbial, antiviral, antibacterial, anti-inflammatory, anti-dermatitis, and diuretic effects (Demirezer 1993, Litvinenko et al. 2003, Mothana et al. 2010, Karataş 2013). Like sorrel (Rumex acetosa L.), other raw vegetables should be consumed not only to form a diet and meal, but also as purifier, remedial, and protector against diseases as the key for a healthy life. For these reasons, vegetables are examined in terms of their substances, and the term "functional nourishment" has been introduced to us. Functional nourishment is identified as nutrients and nutrient components that provide benefits for human physiology and metabolic functions and thus, constitute a protection against diseases and a healthier life besides fulfilling the need for the essential nutrients. These nutrients are expected to provide benefits for one or more body functions by reducing the risk of becoming sick (Boyacioğlu 2013, Akan et al. 2013, Sönmez and Ellialtıoğlu 2014).In order to reach a high level of yield in vegetable farming (Stewart et al. 2005), the maximum growth (Badr and Fekry 1998, Arisha and Bardisi 1999, Arisha and Gad 2003, Dauda et al. 2008)and the amount of inorganic fertilizers as the primary source of herb nutrients are important and emphasized increasingly in the recent years (Adediran et al. 2004, Naeem et al. 2006). Plants take nitrogen as inorganic ion $\left(\mathrm{NH}_{4}^{+}\right.$and $\left.\mathrm{NO}_{3}^{-}\right)$or organic nitrogen (N) (Barker 1975, Gagnon and Berrourard 1994, Montagu and Goh 1990, SandovalVilla et al. 1999).Nitrogen has an important role in the yield formation and quality of the plant (Bellitürk and Sağlam 2005, Lemaire and Gastal 2009).It is a wellknown fact that the application of increasing amounts of nitrogen fertilizer affects the plant yield in a positive way. However, increasing nitrogen fertilization may affect some agronomic characteristics of the product, macro or micro nutrient content, vitamin and protein account and quality positively or negatively. Nitrogen is an important part of many genetic and metabolic compounds such as chlorophyll and amino acids in plant cells. In excessive nitrogen applications, the unused nitrogen in soil causes environmental pollution (Zand-Parsa et al. 2006, Gollany et al. 2004, Beman et al. 2005) and deposition of detrimental compounds in vegetables (Ruiz and Romero 1999). For this reason, the management and programming of nitrogen fertilization is essential in vegetable farming. The color, the content of nutrient, and the taste of tomato are related to the content of antioxidant of the plant (Dumas et al. 2003). When the usable content of nitrogen is limited in the plant, there is more change in phenolic compounds (Haukioja 1998). The phenolic compounds in herbal materials are divided into two parts as "phenolic acids" and "flavonoids" (Cemeroğlu et al 2007). The phenolic compounds have antioxidant effect and this effect is caused by such elements as the purification of free radicals (Rice-Evans et al., 1995, Pekkarinen et al. 1999), composing compounds with metal ions and, preventing or diminishing singlet oxygen composition (Rice-Evans et al. 1995). The phenolic compounds are generally found in leaf, flower, and arboreal part of the plant (Kähkönen et al. 1999).In in vitro studies which deal with the effects of phenolic compounds on health, it has been proved that these compounds have the characteristics of free radical sweeper, enzymatic activity regulator, cell proliferation inhibitor, antibiotic, anti-allergic, anti-diarrheal, antiulcerative, anti-neurodegenerative (Alzheimer and Parkinson protector) (Dzoyem and Eloff 2015), and anti- inflammative (Bravo 1998, Barut Uyar et al. 2013). It has been reported that many medical plants (Kumar et al. 2008, Koleva et al. 2002, Güvenç et al. 2005), vegetables (Çoruh et al. 2007, Brighente et al. 2007, Baravalia et al. 2009) and spices (Hinneburg et al. 2006) are the significant sources of phenolic compounds and have the antioxidant activity.

The conducted studies have proved that the nutrients which are rich for phenolic compounds prevent the free radical formation because of their antioxidant effect (Barut Uyar and Ören 2013). Herbal antioxidant compounds improve the immune system by preventing the free radical formation thus; help the repression of oxidative stress based diseases (Fusco et al. 2007, Adiloğlu et al. 2013, Afacan et al. 2014a).In this respect, for thousands years plants have been the source of medical agents, and many researches have been made on antioxidant compounds of various plants, the antioxidant activity of these compounds and their effects on human health (Humeera et al. 2013, Milella et al. 2014, Afacan et al. 2014b, Jameel et al. 2015).

The target of this study is to reveal the effect of different doses of nitrogen (N) as $\mathrm{NH}_{4} \mathrm{NO}_{3}$ application on the antioxidant activity and phenolic material ingredient of sorrel (Rumex acetosa $\mathrm{L}$.)

\section{MATERIAL AND METHOD}

The research was planned in May 2015 to be conducted at the Laboratory of Soil Science and Plant Nutrition Department of Namik Kemal University 
(Tekirdag), according to randomized blocks experimental design with two replications.

Imported turf was used as production environment in plantation. (Klasmann TS1-Deilmann, Potground H, Germany). Some features of the used turf were the following: $160-260 \mathrm{mg} / \mathrm{L} \mathrm{N}, 180-280$ MG/L N, 180-280 mg/L $\mathrm{P}_{2} \mathrm{O}_{5}, 200-150 \mathrm{mg} / \mathrm{L} \mathrm{K}_{2} \mathrm{O}$, 80-150 mg/L Mg, Ph: 6, \%0.8 N, \%70 organic substance, $\% 35$ C.

In the experiment, four doses of $\mathrm{NH}_{4} \mathrm{NO}_{3}$ fertilizer $\left(\mathrm{N}_{0}: 0 \mathrm{~kg} / \mathrm{da}, \mathrm{N}_{1}: 4 \mathrm{~kg} / \mathrm{da}-16 \mathrm{ppm}, \mathrm{N}_{2}: 6\right.$ $\left.\mathrm{kg} / \mathrm{da}-24 \mathrm{ppm}, \mathrm{N}_{3}: 8 \mathrm{~kg} / \mathrm{da}-32 \mathrm{ppm}\right)$ were used in solution state and a single dose of fertilizer was applied to Rumex, 40 days after the seeding process. The experiment was done in rectangular parcel lands $\left(45 \times 30 \times 15 \mathrm{~cm}^{3}\right)$. Shortly after the harvest, plants were washed with distilled water two times, they were dried in $65{ }^{\circ} \mathrm{C}$ drying-oven till their weight get stabilized, they were ground and prepared fort he analysis. Dried samples were analyzed in the Laboratory of Faculty of Agriculture in Namık Kemal University.

Extraction of Sorrel (Rumex acetosa L.)

\section{Samples}

Dried Rumex samples were treated methanol extraction for five hours by total phenolic compounds assay and DPPH method in order to be used in antioxidant activity determination. After removing methanol from the obtained extracts, they were diluted by definite proportions of methanol and used in the analysis (Humeera et al. 2013).

\section{Determination of Total Phenolic Compounds}

By using $760 \mathrm{~nm}$ wave length gallic acid standard, the total amount of phenolic compounds is determined as $\mathrm{mg} / \mathrm{g}$ with Folin- Ciocalteu reagent (Frank et al. 2004, Cemeroğlu et al 2007).

\section{DPPH Method}

Determination of Antioxidant Activity by

DPPH (1,1-diphenyl-2-picrylhydrazyl) method is based on the measurement of reduction ability of antioxidant compounds, which exist in the sample against DPPH radical, a purple colored compound (Frank et al. 2004, Cemeroğlu et al 2007). Alterations in the absorbance values of radical solution were determined as $517 \mathrm{~mm}$ wave length. The results of the analysis were evaluated by "EC 50 " value (Cemeroğlu 2010).

\section{RESULTS AND DISCUSSION}

Total phenolic material amounts (TPMA) of the Rumex extracts, to which four different doses of
$\mathrm{NH}_{4} \mathrm{NO}_{3}$ had been applied in solution state, were evaluated by using gallic acid standard graphic (Figure 1). The phenolic compound amount, the equivalent of absorbance values, which were obtained for samples, in terms of gallic acid, was found by means of standard curve and total phenolic material amount was calculated as gallic acid equivalent. Total phenolic material amounts (TPMA) of the samples were given in Table 1.

When Table 1 is examined, it is found that according to check sample $\left(\mathrm{N}_{0}\right)$ the highest TPMA can be seen in the second nitrogen application $\left(\mathrm{N}_{2}\right)$ with the value of $72.70 \pm 1.8 \mathrm{mg}$ TPMA/g. When TPMA increased values of the other doses were examined according to control, the increase in the values of the phenolic material could be seen in the first $\left(\mathrm{N}_{1}, 54.95 \pm\right.$ $2.1 \mathrm{mg} / \mathrm{g})$ and in the third doses $\left(\mathrm{N}_{3} 52.20 \pm 1.1 \mathrm{mg} / \mathrm{g}\right)$ when they were compared to check samples. Total phenolic material concentration of Rumex show differences according to kind, solvent and standard solution that are used in the analysis (Uyar and Ören 2013).

As a result of the analysis done with different kinds of Rumex, total phenolic material content of it was determined as a value between $12.27 \mathrm{mg}$ and 26.78 mg tannic acid equivalent per $100 \mathrm{~g}$ by Jimoh et al. (2008), $160.53 \mathrm{mg} / 100 \mathrm{gr}$ by Uyar and Ören. (2013), $121.80 \pm 0.03 \mathrm{mg}$ gallic acid (GA) by Khan et al. (2014). In his study about the examination of antioxidant activity of some plants, whose leaves are consumed as salad-spice, Issbilir (2008) stated that total phenolic material amounts of the extracts were in the range between 49,63 $\pm 2,5-127,55 \pm 14,48 \mathrm{mg} \mathrm{GA} / \mathrm{g}$, they were changed between 24,08 $\pm 1,67-76,03 \pm$ as a catechol equivalent and the highest amounts were taken from the extracts of Sorrel and poppy.

Although the obtained values were lower than the values, which were found by Uyar and Ören 2013, and Khan et al. (2014), they were between the values stated by İşbilir (2008) and they showed parallelism with that study.

Table 2 shows the $\mathrm{mg}$ amounts which provide the inhibition of the \%50 Rumex samples' DPPH (1,1diphenyl-2-picrylhydrazyl) radicals.

When Table. 2 is examined, it is seen that with the increase of nitrogen amounts, which were applied in different levels, antioxidant activities of the samples were increased. The highest increase in the antioxidant activity was found with the value of $0.17 \pm 0.02 \mathrm{mg}$ (32ppm per $8 \mathrm{~kg}$ ) dried plant weight in the numbered $\mathrm{N}_{3}$ sample which had the most intense nitrogen application. According to check sample $\left(\mathrm{N}_{0}\right)$, as a result 


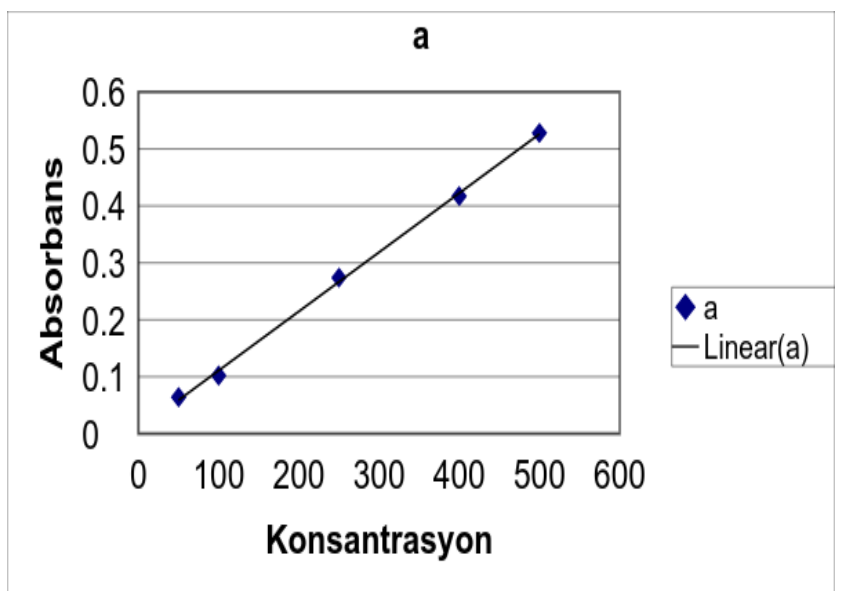

Figure1. Gallic Acid Standard Curve (Absorbance/ Gallic Acid (GA) Concentration mg/L)

Table1.Total phenolic material amounts of Sorrel (Rumex acesto L.) samples (TFMM mg GA/g)

\begin{tabular}{cc}
\hline Sorrel Samples & TFMM $(\mathrm{mg} / \mathrm{g})$ \\
\hline $\mathrm{N}_{\circ}$ & $34.45 \pm 0.1$ \\
\hline $\mathrm{N}_{1}$ & $54.95 \pm 2.1$ \\
\hline $\mathrm{N}_{2}$ & $72.70 \pm 1.8$ \\
\hline $\mathrm{N}_{3}$ & $52.20 \pm 1.1$ \\
\hline
\end{tabular}

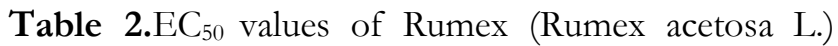
samples (mg dry weight)

\begin{tabular}{ccc}
\hline $\begin{array}{c}\text { Sorrel } \\
\text { Samples }\end{array}$ & $\mathrm{EC}_{50}(\mathrm{mg})$ & $\begin{array}{c}\text { Antioxidant } \\
\text { Activity \% }\end{array}$ \\
\hline $\mathrm{N}_{\mathrm{o}}$ & $0.33 \pm 0.17$ & - \\
\hline $\mathrm{N}_{1}$ & $0.24 \pm 0.16$ & 27 \\
\hline $\mathrm{N}_{2}$ & $0.19 \pm 0.15$ & 42 \\
\hline $\mathrm{N}_{3}$ & $0.17 \pm 0.02$ & 48 \\
\hline
\end{tabular}

of nitrogen applications, percentage increments in antioxidant activity were determined as $\% 27, \% 42$ and $\% 48$ for $\mathrm{N}_{1}, \mathrm{~N}_{2}$ and $\mathrm{N}_{3}$ respectively. Similarly to the phenolic material amounts in the study, the increase in the antioxidant activities of Rumex samples shows parallelism with the increasing $\mathrm{N}$ doses.
It has been concluded that the application of different nitrogen doses has no effect on Rumex's total phenolic material content and antioxidant activity. By contrast with that, in their study, which they examined the effect of nitrogen state, in the bloom period, on the anthocyanin and phenolic development during grape maturation Keller and Hrazdina stated (1998) before pre-bloom stage of grapes, medium level of nitrogen application affects positively the polyphenol synthesis. In the research done by Delgado et al. (2003), they stated that with the increase of nitrogen application, anthocyanin amount and in parallel with that, increase in the color intensity could be observed.

There are different types of Rumex which are used for some diseases like inflammation and constipation. It is indicated that the effect of Rumex acestosa to bodyweight, serum, amino acid and mineral levels (Ladeji et al. 1995), psychopharmacologic and purgative effect of Rumex nepalensis (Ghosh et al. 2002; Ghosh et al. 2003), antioxidative effect of Rumex patienta (Demirezer et al. 2001), antifertility effect of Rumex steudeliin, antimicrobial and anti-inflammatory effect of Rumex nervosus antidiyarheal effect of Rumex maritimus antiviral effect of Rumex bequaerti are derived from the phenolic compounds they include.

Increasing the amount of phenolic compounds and antioxidant group compounds, in which they are included, leads to positive impact on above-mentioned effects of Rumex. In this context, it can be said that increasing phenolic compounds and antioxidant activity, which are obtained as a result of this study, with different dose $\mathrm{N}$ applications can increase the positive effects of this plant to human health. For this reason it's thought that concrete results can be obtained through the studies related to stated matters by supporting the biological activity researches of human.

\section{References}

Adediran A.J. B.L. Taiwo O.M. Akande A.R. Sobule J.O., Idowu. 2004. Application of organic and inorganic fertilizer for sustainable maize and cowpea yields in Nigeria. J. Plant Nutr., 27: 1163-81

Adiloğlu S., Afacan A., Hasanghasemi A., Sağlam. C. 2013. Determination of Antioxidant Activities of Sunflower Plants Growing in Acid Soils during Physiological and Harvesting Period with $\beta$-carotene-linoleic Acid Method. 1st Central Asia Congress On Modern Agricultural Techniques and Plant Nutrition.01-03 October Bishkek/ Kyrgyzstan.

Afacan A., Adiloğlu S., Hasanghasemi A., Sağlam. C. 2014a. Determination of Physiological and Harvest 
Antioxidant Activities of Sunflower Plants Growing in Alkaline Soils with Dpph Method. Journal of Essential Oil Bearing Plants, TEOP. 17(5): 1017 1022

Afacan A., Adiloğlu S., Hasanghasemi, A., Sağlam, C., 2014b. Determination of Antioxidant Activity of Sunflower Growing in Hayrabolu District of Tekirdağ Province. Journal of Tekirdağ Agriculture Faculty. 11: 21 - 26.

Akan S., Veziroğlu S., Özgün Ö., Ellialtıoğlu. Ş. 2013. Turp (Raphanus sativus L.) sebzesinin fonksiyonel gida olarak değerlendirilmesi. Yüzüncü Y1l Üniversitesi Tarım Bilimleri Dergisi. 23(3): 289-295.

Arisha, H.M., Bradisi. A., 1999. Effect of mineral fertilizers and organic fertilizers on growth, yield and quality of potato under sandy soil conditions. Zagazig J. Agric. Res., 26, 391-405.

Arisha H.M.E., Gad S.E. 2003. Younes, Response of some pepper cultivars to organic and mineral nitrogen fertilizer under sandy soil conditions. Zagazig J. Agric. Res., 30:1875-99.

Badr L.A.A., Fekry W.A., 1998. Effect of intercropping and doses of fertilization on growth and productivity of taro and cucumber plants. Vegetative growth and chemical constituents of foliage. Zagazig J.Agric. Res., 25: 1087-1101.

Baravalia Y., Kaneria M., Vaghasiya Y. 2009. Antioxidant and antimicrobial activity of Diospyros ebenum Roxb. Leaf extracts. Turk J Biol 33: 159-164.

Barker A.V. 1975. Organic vs. inorganic nutrition and horticultural crop quality. Hortscience. 10: 50-53.

Barut Uyar B., Gezmen-Karadă̆ M., Şanlıer N., Günyel S. 2013. Toplumumuzda siklıkla kullanılan bazı bitkilerin toplam fenolik madde miktarlarının saptanması. Gida Dergisi. 38 (1) : 23-29.

Baytop T. 1984. Türkiye'de Bitkiler ile Tedavi. İstanbul Üniversitesi Eczacılık Fakültesi Yayınları No: 40, İstanbul.

Belliturk, K. and Saglam, M.T., 2005. A research on the Amount of Mineralized Nitrogen and Mineralization Capacity in the Soils of Tekirdag Province. Journal of Tekirdag Agricultural Faculty, 2 (1): 89-101, Tekirdag.

Beman J.M., Arrigo K.R. P.A. 2005. Matson, Agricultural runoff fuels large phytoplankton blooms in vulnerable areas of the ocean. Nature 434: 211-214.

Boyacioğlu D. 2013. Fonksiyonel gidalar. www.dilekboyacioglu.com/Fonksiyonel Gidalar Roportaj. pdf . Erişim Tarihi: 05.06.2015

Bravo LB. 1998. Polyphenols: chemsitry, dieatry sources, metabolism, and nutritional significance. Nutr Rev. 56, 317-333.

Brighente I.M.C., Dias M., Verdi. L.G. 2007. Antioxidant activity and total phenolic content of some Brazilian species. Pharm Biol 45: 156-161.

Cemeroğlu B. 2010. Gıda Analizleri, Gıda Teknolojisi

Derneği Yayınları, Ankara.

Cemeroglu B., Yemenicioglu A., Özkan M. 2007. Meyve ve Sebze işleme Teknolojisi. 1: 670 Ankara.
Coruh N., Sağdıcoğlu Celep A.G., Ozgokce F. 2007. Antioxidant properties of Prangos ferulacea L., Chaerophyllum macropodum Boiss. and Heracleum persicum Desf. from Apiaceae family used as food in Eastern Anatolia and their inhibitory eff ects on glutathione-S-transferase. Food Chem 100: 1237-1242.

Dauda S.N., Ajayi F.A., Ndor E. 2008. Growth and yield of water melon (Citrullus lanatus) as affected by poultry manure application. J. Agric. Soc. Sci., 4, 121-4.

Delgado R., Martín P., Álamo M., González M.R. 2004. Changes in the phenolic composition of grape berries during ripening in relation to vineyard nitrogen and potassium fertilisation rates. Journal of the Science of Food and Agriculture 84 (7): 623-630.

Demirezer LO., BergereH- J. Schiewe I., Zeeck A. 2001. The structures of antioxidant and cytotoxic agents from natural source: anthraquinones and tannins from roots of Rumex patientia. Phytochemistry, 58, 12131217

Demirezer L.O. 1993. Comparison of two Rumex species with spectrophotometric method and chromatographic identification with regard to anthraquinone derivatives. Planta Med. 59: 630.

Dumas Y., Dadomo M., Lucca G., Grolier P., di Lucca G., 2003. Effects of environmental factors and agricultural techniques on antioxidant content of tomatoes. Journal of the Science of Food and Agriculture 83: 369-382.

Dzoyem JP., Eloff JN. 2015. Anti-inflammatory, anticholinesterase and antioxidant activity of leaf extracts of twelve plants used traditionally to alleviate pain and inflammation in South Africa. Journal of Ethnopharmacology, 160: 194-201.

Fusco D., Colloca G., Lo Monaco M.R., Cesari M. 2007. Effects of antioxidant supplementation on the aging process. Clinical Interventions in Aging 2: 377-387.

Frank M.J., Seeberger L.C., O’Reilly R.C. 2004. By carrot or by stick: Cognitive reinforcement learning in Parkinsonism. Science, 306: 1940-1943.

Gagnon B., Berrouard S. 1994. Effects of several organic fertilisers on growth of greenhouse tomato transplants. Canadian Journal of Plant Science 74, 167-168.

Ghosh L., Arunachalam G., Murugesan T., Pal M., Saha BP. 2002. Studies on the psychopharmacological activities of Rumex nepalensis Spreng. root extract in rats and mice. Phytomedicine, 9: 202-206.

Ghosh L., Gayen JR., Murugesan T., Sinha S., Pal M., Saha BP. 2003. Evaluation of purgative activity of roots of Rumex nepalensis. Fitoterapia. 74: 372-374.

Gollany H.T., Molina J.E., Clapp C.E., Allmaras R.R., Layese M.F., Baker J.M., Cheng H.H. 2004. Nitrogen leaching and denitrification in continuous corn as related to residue management and nitrogen fertilisation, Environmental Management 33: 289-298. 
Guvenc A., Houghton P.J., Duman H. 2005. Antioxidant activity studies on selected Sideritis species native to Turkey. Pharm Biol 43 : 173-177.

Haukioja E., Ossipov V., Koricheva J., Honkanen T., Larsson S., Lempa K. 1998. Biosynthetic origin of carbon-based secondary compounds: cause of variable responses of woody plants to fertilization? Chemoecology 8: 133-139.

Hinneburg I., Dorman H.J.D., Hiltunen R. 2006. Antioxidant activities of extracts from selected culinary herbs and spices. Food Chem 97: 122-129.

Humeera N., Kamili AN., Bandh SA., Amin S., Lone BA., Gousia N. 2013. Antimicrobial and antioxidant activities of alcoholic extracts of Rumex dentatus L., Microbial Pathogenesis 57: 17-20.

İşbilir S.Ş. 2008. Yaprakları Salata-Baharat Olarak Tüketilen Baz1 Bitkilerin Antioksidan Aktivitelerinin İncelenmesi. Doktora Tezi Trakya Üniversitesi Fen Bilimleri Enstitüsü.

Jimoh FO, Adedapo, AA., Aliero AA., Afolayan AJ. 2008. Pholyphenolic contents and biological activities of rumex ecklonianus. Pharm Biol, 46(5) : 333-340.

Jameel M., Ali A., Ali M. 2015. Isolation of antioxidant phytoconstituents from the seeds of Lens culinaris Medik, Food Chemistry 175: 358-365.

Karataş F. 2013. Kuzukulağı (Rumex acetosella L.) Bitkisinin A, E ve C Vitamini İçeriğinin Belirlenmesi. Suleyman Demirel Universitesi, Journal of Natural and Applied Science, 17(1) : 60-63.

Kähkönen M.P. Hopia A.I., Vuorela H.J., Rauha J.P., Pihlaja K., Kujala T.S., Heinonen M. 1999. Antioxidanat activity of planat extracts containing phenolic compounds. J. Agric. Food Chem. 47: 3954-3962.

Khan T.H., Ganaie M.A., Siddiqui N.A., Alam A., Ansari M.N. 2014. Antioxidant potential of Rumex vesicarius L.: in vitro approach. Asian Pac J Trop Biomed. 4(7): 538-544.

Keller M., Hrazdina G. 1998. Interaction of nitrogen availability during bloom and light intensity during veraison. II. Effects on anthocyanin and phenolic development during grape ripening. Am J Enol Vitic 49: 341-349

Koleva I.I., Van Beek T.A., Linssen J.P.H. 2002. Screening of plant extracts for antioxidant activity: a comparative study on three testing methods. Phytochem Anal 1: 8-17.

Kumar P.S., Sucheta S., Deepa V.S. 2008. Antioxidant activity in selected Indian medicinal plants. African J Biotechnol 7: 1826-1828.

Ladeji O., Okoye ZSC., Waidu Z. 1995. Effect of supplementation laboratory chow with leaf of rumex acetosa (sorel) on body weight and serum levels of amino acids and minerals in rats. Food Chem, 59: 1517

Lemaire G., Gastal F. 2009. Quantifying crop responses to nitrogen deficiency and avenues to improve nitrogen use efficiency. In: Sadras, V.O., Calderini, D.F.(Eds.),
Crop Physiology.Applications for Genetic Improvement andAgronomy. Elsevier, Burlington, Massachusetts. 171-211.

Litvinenko Y.A., MuzychKina R.A. 2003. Phytochemical investigation of biologically active substances in certain Kazakhstan Rumex species. Chem Nat Comp; 39(5) : 368-370.

Ladeji O., Okoye ZSC., Waidu Z. 1995. Effect of supplementation laboratory chow with leaf of rumex acetosa (sorel) on body weight and serum levels of amino acids and minerals in rats. Food Chem, 59: 1517

Mothana R.A.A., Abdo S.A.A., Hasson S., Althawab F.M.N., Alaghbari S.A.Z., Lindequist U., 2010. Antimicrobial,antioxidant and cytotoxic activities and phytochemicalscreening of some Yemeni medicinal plants. Evid Based Complement Alternat Med; 7(3) : 323-330.

Montagu K.D., Goh K.M. 1990. Effects of forms and rates of organic and inorganic nitrogen fertilisers on the yield and some quality indices of tomateos (Lycopersicon esculentum Miller). New Zealand Journal of Crop and Horticultural Science 18: 31-37.

Millealla L., Bader A., Tomassi ND., Russo D., Braca A. 2014. Antioxidant and free radical-scavenging activity of constituents from two Scorzonera species Food Chemistry 160: 298-304.

Naeem M., Iqbal J., Bakhsh M.A.A. 2006. Comparative Study of Inorganic Fertilizers and Organic Manures on Yield and Yield Components of Mungbean (Vigna radiat L.). J. Agric. Soc. Sci., 2: 227-9

Pekkarinan S.S., Heinonen I.M., Hopia A.I. 1999. Flavonoids quercetin, myricetin, kaemferol and $(+)$-catechin as antioxidants in methyl linoleate. J. Sci. Food Agric. 79: 499-506.

Rice-Avans C.A. Miller N.J., Bolwell P.G., Bramley P.M., Pridham J.B. 1995. the relative antioxidant activities of plant-derived polyphenol flavonoids. Free Radical Research. 22 (4) : 375-383.

Ruiz J.M. Romero L. 1999. Cucumber yield and nitrogen metabolism in response to nitrogen supply.Scientia Horticulturae 82: 309-316.

Sandoval-Villa M., Wood C.W., Guertal E.A. 1999. Effects of nitrogen form, nighttime nutrient solution strength, and cultivar on greenhouse tomato production. Journal of Plant Nutrition 22: 1931-1945.

Sönmez K., Ellialtıoğlu Ş.Ş. 2014. Domates, karotenoidler ve bunları etkileyen faktörler üzerine bir inceleme. Derim, 31 (2) : 107-130.

Stewart M.W. Dibb W.D., Johnston E.A., Smyth J.T. 2005. The contribution of commercial fertilizer, Nutrients to Food Production. Agron. J., 97: 1-6.

Tabata M., Sezik E.G., Honda E., Yeşilada H., Fukui K., Goto Ikeshiro Y. 1994. Traditional medicine in Turkey III. Folk Medicine in East Anatolia, Van and Bitlis Provinces. Inter. Journal Pharm., 32: 3-12. 
Uyar G., Ören M. 2013. Three remarkable new moss records for South-West Asia from northern Turkey. Turk. J. Bot. 37: 363-368.

Vural H., Eşiyok D., Duman, İ. 2000. Kültür Sebzeleri (Sebze Yetiştiriciliği). Ege Üniversitesi Yayını, Bornova, İzmir.

Zand-Parsa S., Sepaskhah AR., Rownaghi A., 2006. Development and evaluation of integrated water and nitrogen model for maize. Agricultural Water Management 81: 227-256.

Submitted: 22.10 .2015

Accepted: 11.12.2015 